Reforming Fictions 



\section{Reforming Fictions}

Native, African, and Jewish American Women's

Literature and Journalism in the Progressive Era

\section{Carol J. Batker}

Columbia University Press NEWYORK 
Columbia University Press

Publishers Since I893

New York Chichester, West Sussex

Copyright (C) 2000 Columbia University Press

All rights reserved

Library of Congress Cataloging-in-Publication Data

Batker, Carol J.

Reforming fictions : Native, African, and Jewish American women's literature and journalism in the progressive era / Carol J. Batker.

p. $\mathrm{cm}$.

Includes bibliographical references and index.

ISBN 0-23I-II850-3 (casebound : acid-free paper) - ISBN 0-23I-II85I-I (pbk.)

I. American prose literature-Minority authors-History and criticism. 2. Social problems in literature. 3. Women and literature-United States-History-2oth century. 4. Women in journalism-United States-History-2oth century.

5. Social problems-United States-History-2oth century. 6. American fiction-Women authors-History and criticism. 7. American fiction-2oth century-History and criticicm. 8. Journalism-United States-History-2oth century. 9. Fauset, Jessie Redmon-Political and social views. Io. Women social reformers-United States. I. Title.

$\mathrm{PS}_{3} 66 . \mathrm{S} 62 \mathrm{~B}_{3} 82000$

$8 \mathrm{I} 8^{\prime} .508099287^{\prime} 08693$-dc2 I

99-089025

$\infty$

Casebound editions of Columbia University Press books are printed on permanent and durable acid-free paper.

Printed in the United States of America

c IO $98765432 \mathrm{I}$

p IO 98765432 I 
For Barry, Olivia, and Aaron 
